\title{
A Study on Evaluation on Innovation Efficiency of Advanced Manufacturing in China
}

\author{
Shuili Yang ${ }^{1, \mathrm{a}}$, Lei $\mathrm{Li}^{* 2, \mathrm{~b}}$ \\ ${ }^{1}$ School of Economics and Management, Xi'an University of Technology, Xi'an, China \\ ${ }^{2}$ School of Economics and Management, Xi'an University of Technology, Xi'an, China
}

\begin{abstract}
A comprehensive evaluation was conducted on the innovation efficiency of advanced manufacturing in China from 2015 to 2017 with BCC model and super efficiency analysis and based on the data from $184 \mathrm{~A}$-share listed advanced manufacturing companies. The results indicate that the total innovation efficiency, pure technical efficiency and scale efficiency of the advanced manufacturing in China are increasing year by year, especially the scale efficiency increases the most significantly; however, the advanced manufacturing is still at a relatively lower level and shows an unbalanced and insufficient development as a whole. In addition, the total innovation efficiency of 14 sub-sectors of the advanced manufacturing is increasing year by year.
\end{abstract}

\section{Introduction}

China's State Council has unveiled a national plan, dubbed "Made in China 2025" and designed to transform China into a world manufacturing power by "three stages", making clear that China will vigorously develop advanced manufacturing and focus on promoting a rapid development of ten key sub-sectors such as energy conservation and new energy vehicles. The development of advanced manufacturing is an inherent requirement for the transformation and upgrading of China's manufacturing as well as the only way for China to enter the stage of high-quality economic development, and plays an important role in promoting a smooth implementation of the plan "Made in China 2025"[1] . Since the plan "Made in China 2025" has been unveiled for nearly five years, whether the input-output efficiency of advanced manufacturing innovation resources has been significantly improved? Which factors are the keys affecting the innovation efficiency of advanced manufacturing and which aspects still need to be further improved?

Through references review, it can be seen that the study scope mainly includes evaluation methods, evaluation objects, influencing factors, external perspectives and others[2]. Specifically, the evaluation methods include parametric methods[3] represented by stochastic frontier analysis (SFA) of production function, and non-parametric methods[4] represented by data envelopment analysis (DEA). The study objects mainly revolve around strategic emerging industries[5] and high-tech industry[6]; and the influencing factors are centered on R\&D management[7], R\&D investment[8], government subsidies[9], innovation network [10]and others. In addition, the external perspectives are mainly about the value chain perspective[11], incomplete perspective of factor market[12], and resource constraint perspective[13]. The study has an important reference significance for exploring the innovation efficiency of advanced manufacturing, but it still needs further improvement.

The improvement was to be made herein in the following two aspects: firstly, the evaluation index system of innovation efficiency of advanced manufacturing was established, with BCC model to analyze the input-output efficiency and development trend of innovation resources in the advanced manufacturing in China so as to enrich and expand the existing contents; and secondly, the Ashare advanced manufacturing listed enterprises from 2015 to 2017 were selected as samples to make the study representative and practical.

\section{Study Design}

\subsection{Introduction to Evaluation Method}

Firstly proposed by Farrel (in 1957), and then studied and developed by operations research scientist A. Charnes and W. W. Cooper et al. (in 1978) based on the concept of relative efficiency, data envelopment analysis (DEA) is an efficiency analysis and evaluation method aiming at multiple inputs and outputs, among which BCC model is mainly used to evaluate that whether pure technical efficiency is effective. As the advanced manufacturing is featured by high technology, high complexity and significant variable returns to scale, BCC model which is 
more representative and more widely used among DEA models was chosen herein.

\subsection{Evaluation Index System}

The key to evaluate the innovation efficiency of advanced manufacturing is to construct a rational innovation efficiency evaluation index system which includes innovation resource input and output. Specifically, innovation input is mainly reflected in the input of innovation resources at the supply side and the accumulation of existing innovation resources and achievements, while innovation output is mainly reflected in new demands, new models, etc. Based on the continuity and availability of data, the following input-output indexes are adopted to evaluate the input efficiency of innovation resources by reference to relevant literatures and previous results of relevant scholars.

Table.1 Evaluation Index System of Advanced Manufacturing Resource Efficiency

\begin{tabular}{|c|c|c|}
\hline $\begin{array}{l}\text { Index } \\
\text { atrib } \\
\text { ute }\end{array}$ & Index name & Index description \\
\hline & $\begin{array}{l}\text { Proportion of } \\
\text { R\&D personnel }\end{array}$ & $\begin{array}{l}\text { Total number of R\&D personnel in current } \\
\text { year / total number of personnel of enterprises } \\
\text { in current year }\end{array}$ \\
\hline \multirow{3}{*}{$\begin{array}{l}\text { Input } \\
\text { index } \\
\text { es }\end{array}$} & $\begin{array}{l}\text { Proportion of } \\
\text { R\&D } \\
\text { expenditure }\end{array}$ & $\begin{array}{l}\text { Total R\&D expenditure in current year / } \\
\text { operating revenues in current year }\end{array}$ \\
\hline & $\begin{array}{l}\text { Total valid } \\
\text { patents in } \\
\text { current year }\end{array}$ & $\begin{array}{l}\text { Natural logarithm of total valid patents held } \\
\text { by enterprises as of the current year }\end{array}$ \\
\hline & $\begin{array}{l}\text { Strength of } \\
\text { government } \\
\text { subsidies }\end{array}$ & $\begin{array}{l}\text { Total government subsidies in current period / } \\
\text { total assets of enterprises }\end{array}$ \\
\hline \multirow{4}{*}{$\begin{array}{l}\text { Outpu } \\
\mathrm{t} \\
\text { index } \\
\text { es }\end{array}$} & $\begin{array}{l}\text { Product sales } \\
\text { performance }\end{array}$ & Natural logarithm of main operating revenues \\
\hline & $\begin{array}{l}\text { Growth rate of } \\
\text { intangible } \\
\text { assets }\end{array}$ & $\begin{array}{l}\text { Change in intangible assets in current year / } \\
\text { total assets at the end of period }\end{array}$ \\
\hline & $\begin{array}{l}\text { Total patents } \\
\text { applied in } \\
\text { current year }\end{array}$ & $\begin{array}{l}\text { Natural logarithm of total patents applied by } \\
\text { enterprises in current year }\end{array}$ \\
\hline & $\begin{array}{l}\text { Total patents } \\
\text { licensed in } \\
\text { current year }\end{array}$ & $\begin{array}{l}\text { Natural logarithm of total patents licensed to } \\
\text { enterprises in current year }\end{array}$ \\
\hline
\end{tabular}

\subsection{Sample Selection and Data Source}

As of July 2018, there were 2,224 manufacturing listed companies among the A-share listed companies in China, accounting for $63.06 \%$, marking that manufacturing had become the leading force of A-share listed companies. As the senior form and development trend, the advanced manufacturing is an important component leading the structure optimization and high-quality development of manufacturing. As a result, it is more typical and representative to take the advanced manufacturing listed companies as the study objects. In accordance with the Statistical Classification of Emerging Industries, New Business Forms and New Business Models (2018) issued by the National Bureau of Statistics of China in 2018, the manufacturing in China covers 31 types, among which the advanced manufacturing specifically includes 14 subsectors such as new-generation information technology and high-end equipment manufacturing.

\section{Evaluation on Innovation Efficiency of Advanced Manufacturing}

Since the year of 2015 is the first year of reform implementation, the advanced manufacturing companies listed in Shanghai and Shenzhen A-share markets from 2015 to 2017 were selected as the initial samples, and the ST samples among initial samples were deleted. Finally, 184 effective samples were obtained. All these data are from China Stock Market \& Accounting Research Database (CSMAR Database). With the aid of DEA-BCC model, and analysis with deap2.1, the specific results refer to Table

Table. 2 Innovation Efficiency and Proportion of Advanced Manufacturing Enterprises from 2015 to 2017

\begin{tabular}{|c|c|c|c|c|c|c|}
\hline Year & TE & PTE & SE & CRS & IRS & DRS \\
\hline 2015 & 0.715 & 0.917 & 0.776 & $4.35 \%$ & $6.43 \%$ & $89.22 \%$ \\
\hline 2016 & 0.838 & 0.925 & 0.904 & $10.87 \%$ & $9.33 \%$ & $79.80 \%$ \\
\hline 2017 & 0.882 & 0.934 & 0.943 & $14.68 \%$ & $15.14 \%$ & $70.18 \%$ \\
\hline mean & 0.812 & 0.925 & 0.874 & $9.97 \%$ & $10.30 \%$ & $79.73 \%$ \\
\hline
\end{tabular}

The total innovation efficiency is increasing year by year, rising from 0.715 in 2015 to 0.882 in 2017 . The annual average growth rate is $11.07 \%$, showing a significant growth, significantly higher than China's GDP growth rate in the same period. The proportion of total listed companies realizing DEA efficiency is increasing year by year too, rising from $4.35 \%$ in 2015 to $14.68 \%$ in 2017 , but still in a lower size. All these indicate that on the whole, the total innovation efficiency of the advanced manufacturing listed companies in China is not high, there is still a significant gap compared with those realizing DEA efficiency, and the insufficient amount of DEA efficiency decision-making units is one of the important reasons causing a lower total innovation efficiency.

From the perspective of pure technical efficiency, the fluctuation range in the sample period is small and remains at a relatively higher level as a whole, rising from 0.715 in 2015 to 0.882 in 2017 , and showing a three-year average of 0.812 , which is significantly higher than the total innovation efficiency and scale efficiency in the same period. From the perspective of scale efficiency, it shows an increasing trend in the sample period, rising from 0.776 in 2015 to 0.943 in 2017 . From the perspective of increasing scale efficiency, the proportion of the enterprises with increasing scale efficiency shows an overall increasing trend, rising from $6.43 \%$ in 2015 to $15.14 \%$ in 2017 ; the proportion of enterprises with decreasing scale efficiency decreases year by year; and the proportion of enterprises with decreasing scale efficiency and the enterprises with increasing scale efficiency decreases from 13.9 in 2015 to 7.7 in 2017 . All these show that the total innovation efficiency of the advanced manufacturing listed companies in China is 
gradually improving in the sample period. On this basis, 184 sampling enterprises were classified as per the subsectors of advanced manufacturing to obtain the distribution of innovation efficiency of sub-sectors.

Table. 3 Innovation Efficiency of Advanced Manufacturing Sub-sector from 2015 to 2017

\begin{tabular}{|c|c|c|c|c|c|}
\hline $\begin{array}{c}\text { Sub-sectors of } \\
\text { advanced manufacturing }\end{array}$ & Year & TE & PTE & SE & $\begin{array}{c}\text { Scale } \\
\text { type }\end{array}$ \\
\hline \multirow{3}{*}{$\begin{array}{l}\text { New generation information } \\
\text { technology }\end{array}$} & 2015 & 0.661 & 0.892 & 0.736 & drs \\
\hline & 2016 & 0.818 & 0.905 & 0.901 & drs \\
\hline & 2017 & 0.867 & 0.918 & 0.942 & drs \\
\hline \multirow{3}{*}{ High-end equipment } & 2015 & 0.752 & 0.923 & 0.812 & drs \\
\hline & 2016 & 0.860 & 0.926 & 0.926 & drs \\
\hline & 2017 & 0.871 & 0.922 & 0.944 & drs \\
\hline \multirow{3}{*}{$\begin{array}{l}\text { Advanced steel and iron } \\
\text { material }\end{array}$} & 2015 & 0.781 & 0.943 & 0.824 & drs \\
\hline & 2016 & 0.803 & 0.945 & 0.846 & drs \\
\hline & 2017 & 0.883 & 0.955 & 0.925 & drs \\
\hline \multirow{3}{*}{ Advanced nonferrous material } & 2015 & 0.760 & 0.937 & 0.801 & drs \\
\hline & 2016 & 0.846 & 0.952 & 0.885 & drs \\
\hline & 2017 & 0.906 & 0.953 & 0.949 & drs \\
\hline \multirow{3}{*}{$\begin{array}{l}\text { Advanced petrochemical and } \\
\text { chemical }\end{array}$} & 2015 & 0.628 & 0.925 & 0.675 & drs \\
\hline & 2016 & 0.834 & 0.945 & 0.882 & irs \\
\hline & 2017 & 0.932 & 0.971 & 0.959 & drs \\
\hline \multirow{3}{*}{ Advanced inorganic nonmetal } & 2015 & 0.700 & 0.904 & 0.773 & drs \\
\hline & 2016 & 0.777 & 0.908 & 0.852 & drs \\
\hline & 2017 & 0.864 & 0.922 & 0.932 & drs \\
\hline \multirow{3}{*}{$\begin{array}{l}\text { High performance fiber and } \\
\text { compounds }\end{array}$} & 2015 & 0.688 & 0.917 & 0.747 & drs \\
\hline & 2016 & 0.808 & 0.920 & 0.876 & drs \\
\hline & 2017 & 0.869 & 0.938 & 0.924 & drs \\
\hline \multirow{3}{*}{ Cutting-edge new materials } & 2015 & 0.736 & 0.908 & 0.805 & drs \\
\hline & 2016 & 0.845 & 0.928 & 0.908 & - \\
\hline & 2017 & 0.884 & 0.931 & 0.948 & drs \\
\hline \multirow{3}{*}{ Bio-based products } & 2015 & 0.696 & 0.910 & 0.761 & drs \\
\hline & 2016 & 0.851 & 0.944 & 0.898 & drs \\
\hline & 2017 & 0.876 & 0.951 & 0.917 & irs \\
\hline \multirow{3}{*}{ Biomass fuel } & 2015 & 0.770 & 0.944 & 0.816 & drs \\
\hline & 2016 & 0.761 & 0.874 & 0.871 & drs \\
\hline & 2017 & 0.890 & 0.933 & 0.953 & drs \\
\hline \multirow{3}{*}{ Bio-manufacturing } & 2015 & 0.664 & 0.933 & 0.706 & drs \\
\hline & 2016 & 0.767 & 0.903 & 0.847 & drs \\
\hline & 2017 & 0.895 & 0.935 & 0.955 & drs \\
\hline \multirow{3}{*}{$\begin{array}{l}\text { New energy automobile and } \\
\text { related equipment }\end{array}$} & 2015 & 0.756 & 0.945 & 0.796 & drs \\
\hline & 2016 & 0.902 & 0.951 & 0.949 & drs \\
\hline & 2017 & 0.907 & 0.957 & 0.947 & drs \\
\hline \multirow{3}{*}{ New energy equipment } & 2015 & 0.657 & 0.898 & 0.726 & drs \\
\hline & 2016 & 0.861 & 0.921 & 0.933 & drs \\
\hline & 2017 & 0.896 & 0.931 & 0.960 & irs \\
\hline \multirow{2}{*}{$\begin{array}{l}\text { Energy conservation and } \\
\text { environmental protection } \\
\text { equipment and products }\end{array}$} & 2015 & 0.743 & 0.906 & 0.818 & drs \\
\hline & 2016 & 0.841 & 0.904 & 0.928 & drs \\
\hline
\end{tabular}

\begin{tabular}{|l|l|l|l|l|l|}
\hline & 2017 & 0.842 & 0.902 & 0.931 & drs \\
\hline
\end{tabular}

According to Table 3, the PTE of 14 sub-sectors shows a slowly increasing trend on the whole. Except for individual values, the PTE values maintain above 0.9, with a high concentration degree, a small fluctuation range, and a small impact on the TE. From the change trend of TE, the biomass fuel manufacturing shows a "Vshaped" structure, and the remaining 13 sub-sectors shows an increasing trend year by year. Among which, 8 subsectors including the high-end equipment manufacturing, advanced iron and steel materials manufacturing, advanced non-ferrous metal materials manufacturing show a higher increasing trend than the average level of the advanced manufacturing as a whole. In addition, the $\mathrm{SE}$ of the 14 sub-sectors is increasing year by year.

\section{Main Conclusions}

With the innovation efficiency of the advanced manufacturing in China as evaluation object, the data from 184 enterprises listed in Shanghai and Shenzhen Ashare markets from 2015 to 2017 as samples, and based on the input-output overall evaluation analysis with DEABCC model, the main conclusions are as follows:

Firstly, the total innovation efficiency, pure technical efficiency and scale efficiency of the advanced manufacturing in China are increasing year by year, among which the scale efficiency increases the most significantly, and it is the main factor causing an increasing total innovation efficiency year by year. From the perspective of the proportion of enterprises with constant returns to scale, the proportion of units realizing DEA efficiency is still small, and most decision-making units are in the stage of decreasing returns to scale, indicating that although the innovation efficiency of advanced manufacturing listed companies in China shows a significant growth rate, the advanced manufacturing is still at a relatively lower level and shows an unbalanced and insufficient development as a whole.

Secondly, the total innovation efficiency of the 14 subsectors of advanced manufacturing is increasing year by year. Among them, the average innovation efficiency growth rate of 8 sub-sectors including high-end equipment manufacturing is higher than the average of the advanced manufacturing; and that of such 6 sub-sectors including new generation information technology equipment manufacturing is lower than the overall average. The pure technical efficiency of the 14 subsectors shows a slow increasing trend, while the scale efficiency shows a rapid growth trend, which is the main reason influencing the change of the total innovation efficiency of the 14 sub-sectors. Through super efficiency analysis, the relative efficiency ranking of the 14 subsectors can be further obtained, the DEA of cutting-edge new materials is relatively effective and ranks the highest, and the remaining 13 sub-sectors do not realize DEA efficiency. 


\section{Acknowledgment}

Fund projects: National Social Science Foundation (19BJY096); Major theoretical and practical problems research project of Social Sciences in Shaanxi Province (2019z098).

\section{Brief introduction of the authors:}

ShuiLi Yang, professor and doctoral supervisor, School of economics and management, Xi'an University of technology. Research direction: industrial economy.Lei $\mathrm{Li}, \mathrm{PhD}$ candidate, School of economics and management, Xi'an University of technology. Research direction: industrial economy.

\section{References}

1. Q. H. Huang, J. He, Core Competence, Functional Orientation and Development Strategy of China's Manufacturing Industry-A Review of "Made in China 2025" [J]. China Industrial Economy,2015(06):5-17.

2. Claudio Cruz-Cázares, Cristina Bayona-Sáez,Teresa García-Marco.You can't manage right what you can't measure well:Technological innovation efficiency[J].Research Policy,2013,42(6-7).

3. J. Han , Research on Innovation Efficiency of China's High-tech Industry-Empirical Analysis based on SFA method [J]. Scientific research,2010,28(03):467-472.

4. S.K. Zhao , H.Q. Yu , S.L. Gong, Research on innovation efficiency of high-tech enterprises in jilin province based on DEA method [J]. Scientific research management,2013,34(02):36-43.

5. H. Liu , Y.F. Liu , H. Qiao, Research on the Innovation-Driven Development Path of China's Strategic Emerging Industries -Based on the Experience summary of Beijing's Biomedical Industry [J]. Management review,2014,26(12):20-28.
6. W. Liu , Calculation of R\&D and Innovation efficiency of China's High-tech Industry-Based on three-stage DEA model [J]. Mathematical statistics and management,2015,34(01):17-28.

7. W. Xiao , G.B. Lin , Government support, R\&D management, and Technological Innovation Efficiency-Based on empirical Analysis of China's Industrial Sector $[\mathrm{J}]$ Management World,2014(04):71-80.

8. T.B. Zhang, Research on the Development of China's High-tech Industry and its influencing factors [D]. Dongbei University of Finance and Economics,2012.

9. S. Hong, Research on the Relationship between government funding, enterprise investment and innovation efficiency of high-tech Industry [D]. University of Science and Technology of China,2015.

10. M.J. Yu , Pe. GUO, G. ZHANG, Research on the influence of regional innovation network structure on regional innovation efficiency $[\mathrm{J}]$ Science of science and management of science and technology,2013,34(08):56-63.

11. Y.Z. Yu , Research on technological Innovation Efficiency and Its Influencing Factors in China's High-tech Industry -A Two-stage Analysis from the Perspective of value chain $[\mathrm{J}]$. Economic Science,2009(04):62-74.

12. L.W. Cheng, W. Sun , J.Y. Wang, Innovation Efficiency of High-tech Industries from the Perspective of Incomplete Factor Market - A Comparison of allocation efficiency and scale efficiency of Domestic and foreign capital based on three-stage DEA-Windows [J]. Scientific research,2011,29(06):930-938

13. Z.J. Feng, W. Chen, Research on r\&d and Innovation Efficiency of China's High-tech IndustryA New Perspective based on resource-Constrained Two-stage DEA Model [J]. Systems engineering theory and practice,2014,34(5):1202-1212. 